\section{Gold Complexes with Oxygen-containing} Ligands as a Catalyst for Methane Oxidation

\author{
DA Pichugina', NE Kuz'menko ${ }^{1}$ and \\ AF Shestakov ${ }^{2}$ \\ ${ }^{1}$ MV Lomonosov Moscow State University, Department \\ of Chemistry, 1 Leninskie Gory, 119992 Moscow, \\ Russia \\ ${ }^{2}$ Institute of Problems of Chemical Physics RAS, \\ 1 Ave. Akad. Semenova, 142432 Chernogolovka, \\ Moscow Region, Russia
}

\begin{abstract}
The reactions of methane with the gold complexes $[\mathrm{Au}(\mathrm{OH})]^{-},\left[\mathrm{Au}\left(\mathrm{OCH}_{3}\right)_{4}\right]^{-},\left[\mathrm{Au}\left(\mathrm{O}(\mathrm{CO})_{2} \mathrm{O}\right)_{2}\right]^{-}$and $\left[\mathrm{Au}\left(\mathrm{O}_{2} \mathrm{CH}\right)_{2}\right]^{+},\left[\mathrm{Au}^{\prime}(\mathrm{acac})\right],\left[\mathrm{Au}^{\prime \prime \prime}(\mathrm{acac})_{2}\right]^{+}(\mathrm{acac}$ - acetylacetonato) were studied using the DFT/PBE method with the SBK basis set. High activation barriers were obtained for the electrophilic substitution in $[\mathrm{Au}(\mathrm{OH})]^{-},\left[\mathrm{Au}\left(\mathrm{OCH}_{3}\right)_{4}\right]^{-},\left[\mathrm{Au}\left(\mathrm{O}(\mathrm{CO})_{2} \mathrm{O}\right)_{2}\right]^{-}$ and $\left[\mathrm{Au}^{\prime \prime \prime}(\mathrm{acac})_{2}\right]^{+}$complexes, which excludes the possibility that these reactions might proceed under mild conditions. The reactions of the $\left[\mathrm{Au}\left(\mathrm{HCO}_{2}\right)_{2}\right]^{+}$and [Au'(acac)] complexes with methane have rather low energy barriers and proceed through the formation of an intermediate complex. The alternative mechanism of methane oxidation with a gold complex in the presence of oxygen is simulated.
\end{abstract}

\section{Keywords}

Gold complexes, methane activation, quantum chemical methods, DFT

\section{Introduction}

Selective catalytic activation and functionalization of methane in particular, and alkanes in general, to form useful organic compounds, constitutes an important and challenging problem (1). It is well known that saturated hydrocarbons are very inert under normal conditions and react with radicals only, but these processes are poorly selective and are inappropriate for effective practical use. Shilov was the first to demonstrate $\mathrm{C}-\mathrm{H}$ bond activation by metal complexes using the Pt(II) ion as the activating species (2). Shilov proposed that the reaction starts with an oxidative addition but then a proton is lost during the process as in an electrophilic pathway. The Au(III) ion is an analogue of Pt(II), possessing the same $\mathrm{d}^{8}$ electronic configuration, and square-planar Au(III) and Pt(II) chloride complexes have similar electronic characteristics (3). Moreover aromatic compounds are aurated with $\mathrm{AuCl}_{3}$ at lower temperature $(4,5)$ than such compounds are platinated with $\left[\mathrm{PtCl}_{6}\right]^{2-}(6)$. This gives rise to the question: can gold complexes activate $\mathrm{C}-\mathrm{H}$ bonds in alkanes under mild conditions. Homogeneous gold catalysts are already superior to other catalysts (7) and some of gold(I) and gold(III) complexes containing various ligands are used as catalysts for the conversion of the organic compounds (8) and condensation reactions of benzaldehyde (9).

However, alkane functionalization systems based on gold complexes are undeveloped so far. Selective oxidation of methane to methanol catalysed with $\mathrm{C}-\mathrm{H}$ activation by homogeneous cationic gold has been observed (10). Also, enzymatic methane oxidation in the presence of the Aucontaining specific NADH oxidase from Micrococcus luteus has been observed, (11) NADH is hydrogenated form of nicotinamide adenine dinucleotide. These aurophilic bacteria use methane as an additional energy source, especially when the content of more readily available organic compounds in the soil is insufficient. It may be suggested that the first stage of reaction with methane involves formation of a methyl complex $\mathrm{Au}(\mathrm{III})-\mathrm{CH}_{3}$ according to the scheme:

$$
\mathrm{Au}(\mathrm{III})+\mathrm{CH}_{4}=\mathrm{CH}_{3}-\mathrm{Au}(\mathrm{III})+\mathrm{H}^{+}
$$

and then its subsequent reaction with water yields methanol:

$$
\mathrm{CH}_{3}-\mathrm{Au}(\mathrm{III})+\mathrm{H}_{2} \mathrm{O}=\mathrm{Au}(\mathrm{I})+\mathrm{CH}_{3} \mathrm{OH}+\mathrm{H}^{+} \text {. }
$$

The process is further developed catalytically with the participation of molecular oxygen.

The biomimetic model of coupled methane oxidation withtheAu-rutincomplex (rutin=5,7,3',4'-tetrahydrooxyflavon, Figure 1a (12) in the presence of oxygen has been recently documented for the first time (13). To obtain more detailed information on the reaction mechanism, a special study is required.

Therefore, it is of interest to study theoretically the reactivity of actual gold complexes or their models. Essentially, 


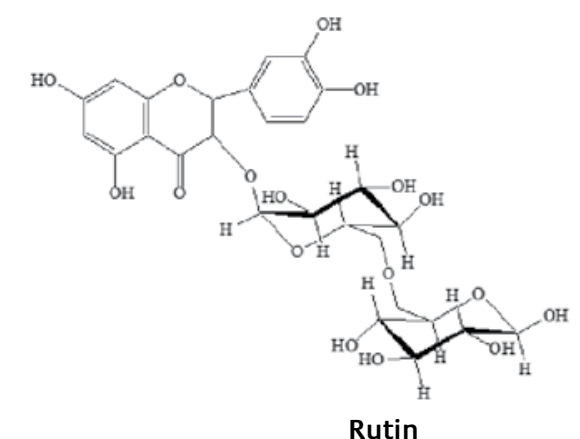

Rutin

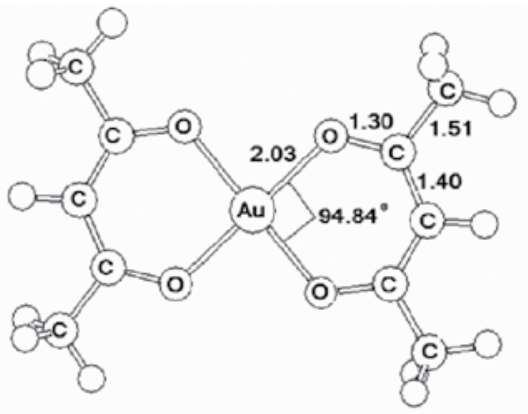

$\mathbf{R}_{6}$

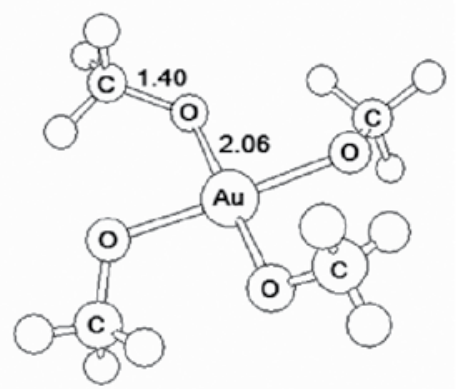

$\mathbf{R}_{2}$
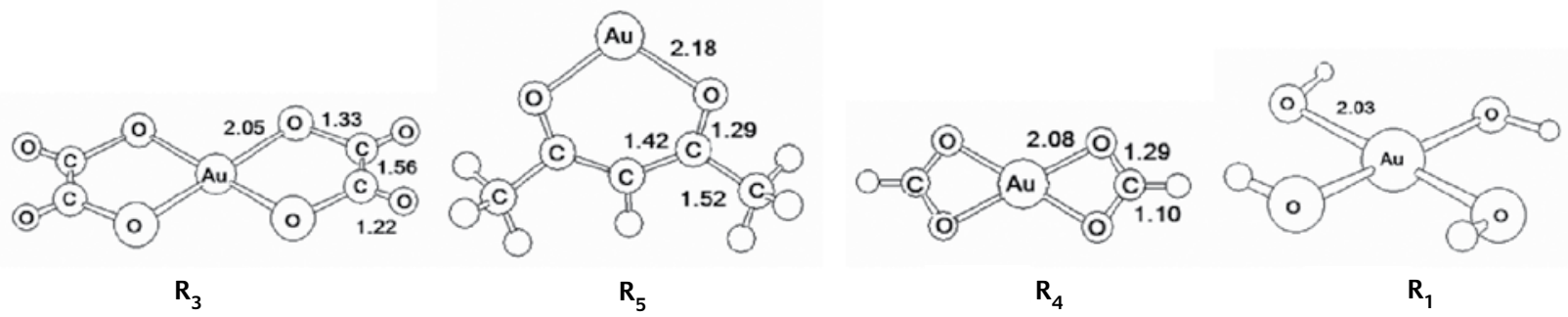

\section{Figure 1}

The structures of rutin (methane oxidation was observed with present of Au-rutin complex (15)) (a) and investigated gold complexes: [Aull(acac) $]^{+}$(b), $\left[\mathrm{Au} u^{\prime}(\mathrm{acac})\right](\mathrm{c}),[\mathrm{Au}(\mathrm{OH})]^{-}(\mathrm{d}),\left[\mathrm{Au}\left(\mathrm{OCH}_{3}\right)_{4}\right]^{-}(\mathrm{e}),\left[\mathrm{Au}(\mathrm{HCOO})_{2}\right]^{+}(\mathrm{f}),\left[\mathrm{Au}\left(\mathrm{O}(\mathrm{CO})_{2} \mathrm{O}_{2}\right]^{-}(\mathrm{g})\right.$ and the calculated bond lengths (A). Hydrogen atoms are not shown

the chemistry of $\mathrm{Au}(\mathrm{III})$ complexes is based on the chemistry of gold chloride which has been more fully investigated (14). Chemical reactions in aqueous solutions currently constitute an important and very active research area. Experimental information concerning the role of the solvent water molecules in the reactions is still very sparse. That is why this is an area where theoretical model calculations are particularly useful in helping to achieve a better understanding. The mechanism of the reactions of methane with the aqua-chloride gold(III) complexes $\left[\mathrm{AuCl}_{x}\left(\mathrm{H}_{2} \mathrm{O}\right)_{4-x}\right]^{3-x}(\mathrm{x}=4,3,2)$ were investigated using different quantum-chemical methods (15). The $\left[\mathrm{AuCl}_{4}\right]^{-}$, $\left[\mathrm{AuCl}_{3}\left(\mathrm{H}_{2} \mathrm{O}\right)\right],\left[\mathrm{AuCl}_{2}\left(\mathrm{H}_{2} \mathrm{O}\right)_{2}\right]^{+}$complexes were considered. High activation barriers were obtained for the reactions of $\left[\mathrm{AuCl}_{4}\right]^{-}$ and $\left[\mathrm{AuCl}_{3}\left(\mathrm{H}_{2} \mathrm{O}\right)\right]$ with methane, thus excluding the possibility that these reactions might proceed under mild conditions. It is interesting that the reaction of the $\left[\mathrm{AuCl}_{2}\left(\mathrm{H}_{2} \mathrm{O}\right)_{2}\right]^{+}$complex with methane has a low energy barrier and proceeds through the formation of an intermediate complex. Keeping in mind these results we carried out simulation of the methane $\mathrm{C}-\mathrm{H}$ bond activation by gold complexes with the oxygen-containing ligands: $[\mathrm{Au}(\mathrm{OH})]^{-}, \quad\left[\mathrm{Au}\left(\mathrm{OCH}_{3}\right)_{4}\right]^{-}$, $\left[\mathrm{Au}\left(\mathrm{O}(\mathrm{CO})_{2} \mathrm{O}\right)_{2}\right],\left[\mathrm{Au}(\mathrm{HCOO})_{2}\right]^{+},\left[\mathrm{Au} \mathbf{l}^{\prime}(\mathrm{acac})\right]$, and $\left[\mathrm{Au} \mathrm{u}^{\prime \prime \prime}(\mathrm{acac})_{2}\right]^{+}$ (acac - acetylacetonato) (Figures 1b-g).

\section{Calculation details}

All calculations were carried out using density functional theory and the nonempirical local PBE (Perdew-BurkeErnzerhof) functional (16), which we have used earlier in the study of gold complexes (17), Calculations were performed with the use of the PRIRODA program (18).
The basis set with the SBK pseudopotential (19) was used. In this pseudopotential, the outer electron shells are described by the following basis sets: H [311/1], C [311/311/11], O [311/311/11], and Au [51111/51111/5111]. The types of stationary points on potential energy surfaces were determined from the analysis of Hessians; the second derivatives were calculated analytically. The nature of transition states was confirmed by calculations of the intrinsic reaction coordinate (20). The zero-point energy was calculated in the harmonic approximation.

\section{Results and discussion}

\section{Simulation of the reaction of $\left[\mathrm{AuL}_{4}\right]$ complexes $\left(\mathrm{L}=\mathrm{OH}, \mathbf{O C H}_{3}\right)$ with methane}

As reported earlier, the $\mathrm{C}-\mathrm{H}$ activation in methane had high activation energy for an oxidative addition pathway (15). That is why we considered electrophilic substitution only:

$$
\begin{aligned}
& {\left[\mathrm{Au}(\mathrm{OH})_{4}\right]^{-}+\mathrm{CH}_{4}=\left[\mathrm{Au}\left(\mathrm{CH}_{3}\right)(\mathrm{OH})_{3}\right]^{-}+\mathrm{H}_{2} \mathrm{O},} \\
& {\left[\mathrm{Au}\left(\mathrm{OCH}_{3}\right)_{4}\right]^{-}+\mathrm{CH}_{4}=\left[\mathrm{Au}\left(\mathrm{CH}_{3}\right)\left(\mathrm{OCH}_{3}\right)_{3}\right]^{-}+\mathrm{CH}_{3} \mathrm{OH} .}
\end{aligned}
$$

To test the ability of these complexes to react with methane, the energies and the structures of the initial compounds $\left(R_{1}, R_{2}\right)$, reaction products $\left(P_{1}, P_{2}\right)$, and transition states $\left(\mathrm{TS}_{1}, \mathrm{TS}_{2}\right)$ were calculated. The $\left[\mathrm{Au}(\mathrm{OH})_{4}\right]^{-}$and $\left[\mathrm{Au}\left(\mathrm{OCH}_{3}\right)_{4}\right]^{-}$anions in the ground state $\left({ }^{1} \mathrm{~A}_{1 \mathrm{~g}}\right)$, like other $\mathrm{d}^{8}$ transition metal complexes, have square-planar structures (Figure 1b,c) with calculated Au-O distances equal to 2.03 and $2.06 \AA$. The optimized structures of the $\left[\mathrm{Au}\left(\mathrm{CH}_{3}\right)(\mathrm{OH})_{3}\right]^{-}$ 


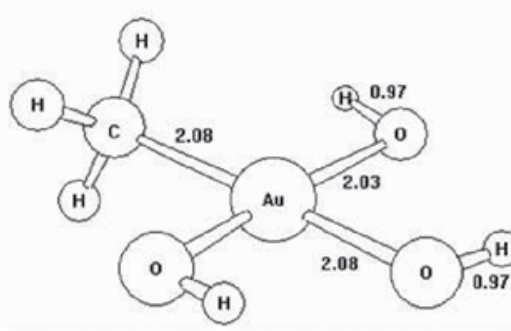

$P_{1}$

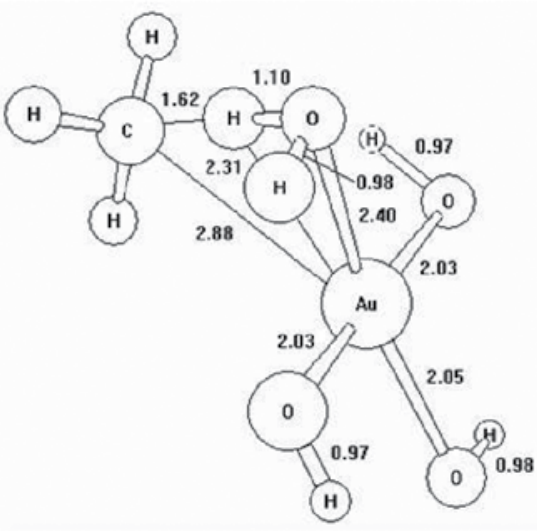

$\mathrm{TS}_{1}$

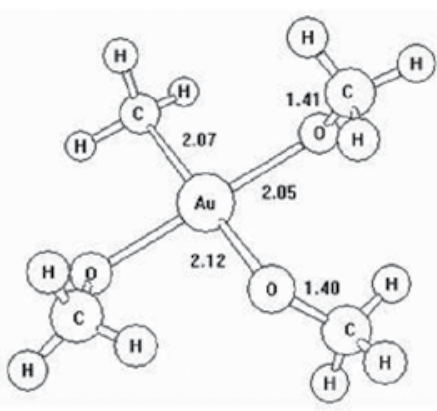

$P_{2}$

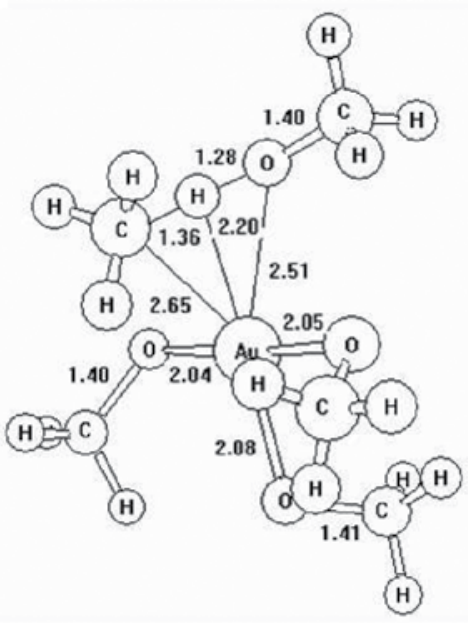

$\mathrm{TS}_{2}$

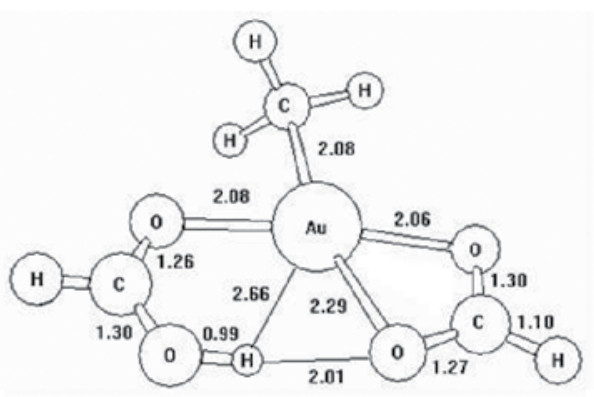

$P_{3}$

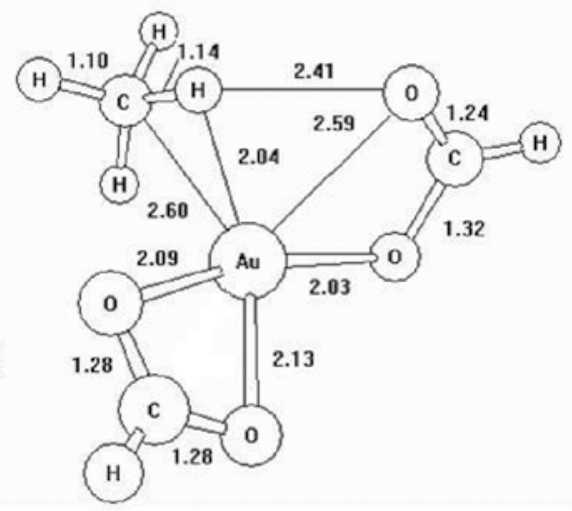

$\mathrm{TS}_{3}$

\section{Figure 2}

Structures of the $\left[\mathrm{Au}\left(\mathrm{CH}_{3}\right)(\mathrm{OH})_{3}\right]^{-},\left[\mathrm{Au}\left(\mathrm{CH}_{3}\right)\left(\mathrm{OCH}_{3}\right)_{3}\right]^{-},\left[\mathrm{Au}\left(\mathrm{CH}_{3}\right)(\mathrm{HCOO})(\mathrm{OCHOH})\right]^{-}$complexes $\left(P_{1}, P_{2}, \mathrm{P}_{3}\right)$, transition states of reactions (3), (4) and (5) (TS, $\mathrm{TS}_{2}$, $T_{3}$ ) and the calculated bond lengths ( $(\hat{A})$

and $\left[\mathrm{Au}\left(\mathrm{CH}_{3}\right)\left(\mathrm{OCH}_{3}\right)_{3}\right]$ - complexes produced in the reactions (3) and (4) are shown in Figure 2. All Au, O, and C atoms are in one plane. The distance from the Au atom and the $\mathrm{O}$ atom in the trans position to the $\mathrm{CH}_{3}$ group is $2.08 \AA$ (or $2.12 \AA$ ) larger than two other equivalent Au-O bond lengths. This is associated with the trans effect of the methyl group, which appears when the ligands occupying the trans positions differ from each other substantially in donor ability. These effects are very interesting but are outside the scope of this work. The structures of $\mathrm{TS}_{1}, \mathrm{TS}_{2}$ are shown in Figure 2. They can be qualified as the later transition states for short $\mathrm{H}$-O bonds are shorter, 1.10 or $1.28 \AA$, respectively (the $\mathrm{C}-\mathrm{H}$ distances are 1.62 or $1.36 \AA$ ). On the other hand the distances between the $C$ and $A u$ atoms in both complexes are still long (2.88 and $2.65 \AA$ A). The result of quantum-chemical simulation of reactions (3) and (4) is presented in the energy diagram (Figure 3). The sum of the energies of reactants was assumed as the zero level. Although both reactions are exothermic (-13.5 and $-11.5 \mathrm{kcal} / \mathrm{mol}$ ) the energy of $\mathrm{TS}_{1}$ and $\mathrm{TS}_{2}$ (41.6 and $40.4 \mathrm{kcal} / \mathrm{mol})$ are much higher.

\section{Simulation of the reaction of $\left[\mathrm{Au}\left(\mathrm{O}(\mathrm{CO})_{2} \mathrm{O}\right)_{2}\right]^{-}$anion with methane}

In this complex the gold atom has ligands of a bidentant type which differ from ligands of $\left[\mathrm{Au}(\mathrm{OH})_{4}\right]^{-}$and $\left[\mathrm{Au}\left(\mathrm{OCH}_{3}\right)_{4}\right]^{-}$

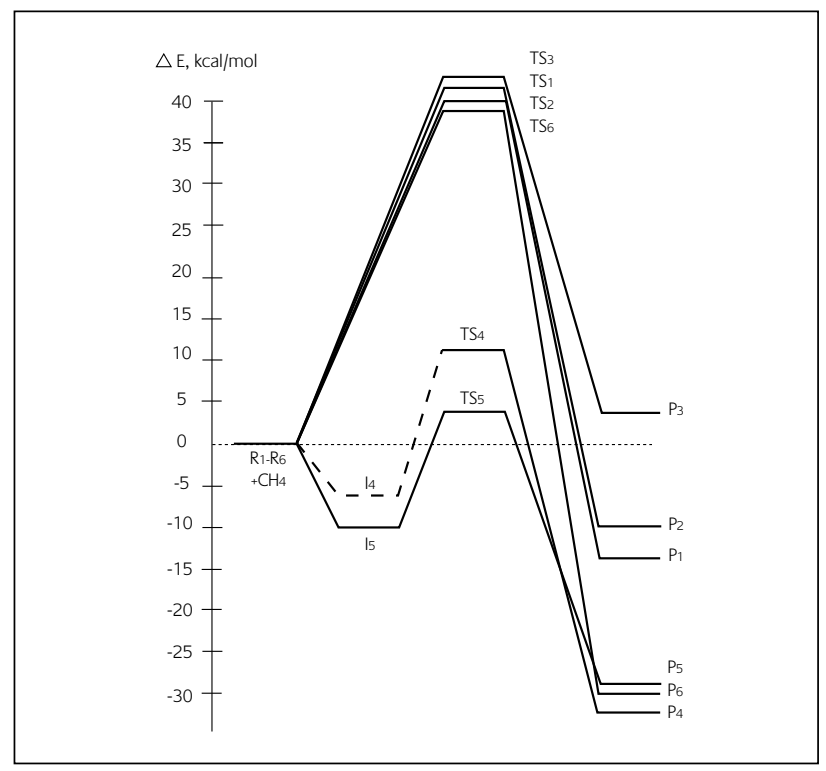

Figure 3

Energy diagram for methane activation by the $\left[\mathrm{Au}(\mathrm{OH})_{4}\right]^{-}\left(R_{1}, \mathrm{TS}_{1}\right)$, $\left[\mathrm{Au}\left(\mathrm{OCH}_{3}\right)_{4}\right]^{-}\left(\mathrm{R}_{2}, \mathrm{TS}_{2}\right),\left[\mathrm{Au}\left(\mathrm{O}(\mathrm{CO})_{2} \mathrm{O}\right)_{2}\right]^{-}\left(\mathrm{R}_{3}, \mathrm{TS}_{3}\right),\left[\mathrm{Au}(\mathrm{HCOO})_{2}\right]^{+}\left(\mathrm{R}_{4}, \mathrm{TS}_{4}\right)$, $[\mathrm{Au}(\mathrm{acac})]\left(R_{5}, T S_{5}\right),\left[\mathrm{Au}(\mathrm{acac})_{2}\right]^{+}\left(R_{6}, \mathrm{TS}_{6}\right)$ complexes with formation of the corresponding methyl derivates: $\left[\mathrm{Au}\left(\mathrm{CH}_{3}\right)(\mathrm{OH})_{3}\right]^{-}(\mathrm{P}),\left[\mathrm{Au}\left(\mathrm{CH}_{3}\right)\left(\mathrm{OCH}_{3}\right)_{3}\right]^{-}$ $\left(\mathrm{P}_{2}\right),\left[\mathrm{Au}\left(\mathrm{CH}_{3}\right)\left(\mathrm{O}(\mathrm{CO})_{2} \mathrm{O}\right)\left(\mathrm{O}(\mathrm{CO})_{2} \mathrm{OH}^{-}\left(\mathrm{P}_{3}\right),\left[\mathrm{Au}\left(\mathrm{CH}_{3}\right)(\mathrm{HCOO})(\mathrm{OCHOH})\right]^{+}\right.\right.$ $\left(\mathrm{P}_{4}\right),\left[\mathrm{Au}\left(\mathrm{CH}_{3}\right)(\mathrm{acacH})\right]\left(\mathrm{P}_{5}\right),\left[\mathrm{Au}\left(\mathrm{CH}_{3}\right)(\mathrm{acac})(\mathrm{acacH})\right]^{+}\left(\mathrm{P}_{6}\right)$. The reactions between methane and $\left[\mathrm{Au}(\mathrm{HCOO})_{2}\right]^{+}$or $[\mathrm{Au}(\mathrm{acac})]$ complexes are passed through methane complex formation $\left(I_{4}, I_{5}\right)$ 
complexes (Figure 1). So, the methane reaction with the $\left[\mathrm{Au}\left(\mathrm{O}(\mathrm{CO})_{2} \mathrm{O}\right)_{2}\right]^{-}$complex proceeds by keeping the protoned group in its coordination sphere. This is accompanied by the ligand coordination change: from bidentant to monodentant type (Figure 2):

$$
\left[\mathrm{Au}\left(\mathrm{O}(\mathrm{CO})_{2} \mathrm{O}\right)_{2}\right]^{-}+\mathrm{CH}_{4}=\left[\mathrm{Au}\left(\mathrm{CH}_{3}\right)\left(\mathrm{O}(\mathrm{CO})_{2} \mathrm{O}\right)\left(\mathrm{O}(\mathrm{CO})_{2} \mathrm{OH}\right)\right]^{-}
$$

The structure of the transition state $\left(\mathrm{TS}_{3}\right)$ corresponding to the reaction of methane with the $\left[\mathrm{Au}\left(\mathrm{O}(\mathrm{CO})_{2} \mathrm{O}\right)_{2}\right]^{-}$anion is shown in Figure 2. The transition state is analogous to $\mathrm{TS}_{1}$ and $\mathrm{TS}_{2}$, and it is apparently at an early stage because the distance between the $\mathrm{C}$ atom and the leaving $\mathrm{H}$ atom (1.14 $\AA$ ) is only slightly longer than the $\mathrm{C}-\mathrm{H}$ bond in methane (1.10 $\AA$ ). The reaction (5) (see the energy diagram in Figure 3 ) is accompanied by an energy loss of $4.6 \mathrm{kcal} / \mathrm{mol}$ and has a higher energy barrier $(43.8 \mathrm{kcal} / \mathrm{mol})$.

\section{Simulation of the $\left[\mathrm{Au}(\mathrm{HCOO})_{2}\right]^{+}$cation reaction with methane}

This complex $\left(R_{4}\right)$ is an analogue of the gold(III) diformate complex which is known to exist. The calculations demonstrated that it has a planar structure with AuO distances equal to $2.08 \AA$. The reaction of $R_{4}$ with methane is as follows:

$$
\left[\mathrm{Au}(\mathrm{HCOO})_{2}\right]^{+}+\mathrm{CH}_{4}=\left[\mathrm{Au}\left(\mathrm{CH}_{3}\right)(\mathrm{HCOO})(\mathrm{OCHOH})\right]^{+}
$$

This is analogous to reaction (5).

The optimized structure of the product $\mathrm{P}_{4}$ looks like the $\mathrm{P}_{3}$ previously described: one Au-O bond breaks off and new Au- $\mathrm{C}$ and $\mathrm{O}-\mathrm{H}$ bonds are formed (Figure 4). The transition state $\mathrm{TS}_{4}$ of the substitution reaction (6), can be seen to be an early state because the distance between the $C$ atom and the leaving $\mathrm{H}$ atom $(1.25 \AA)$ is only slightly longer than the $\mathrm{C}-\mathrm{H}$ bond in methane. Consequently, the methyl ligand is incompletely bound to the Au atom, and the Au-C distance $(2.38 \AA)$ is substantially longer than that in the product (2.08 $\AA)$. The relaxation of $\mathrm{TS}_{4}$ along the reaction coordinates toward the starting compound shows that the reaction takes place through methane complex formation similar to methane activation by the $\left[\mathrm{Au}\left(\mathrm{H}_{2} \mathrm{O}\right)_{2} \mathrm{Cl}_{2}\right]^{+}$complex (15). In view of the fact that the potential energy surface is a flat type we didn't succeed in its full optimization. A new reaction pathway through the transformation of intermediate methane complexes into the corresponding methyl complexes has a low energy barrier of $10.6 \mathrm{kcal} / \mathrm{mol}$ relative to the initial compounds. So reaction (6) becomes possible in the mild

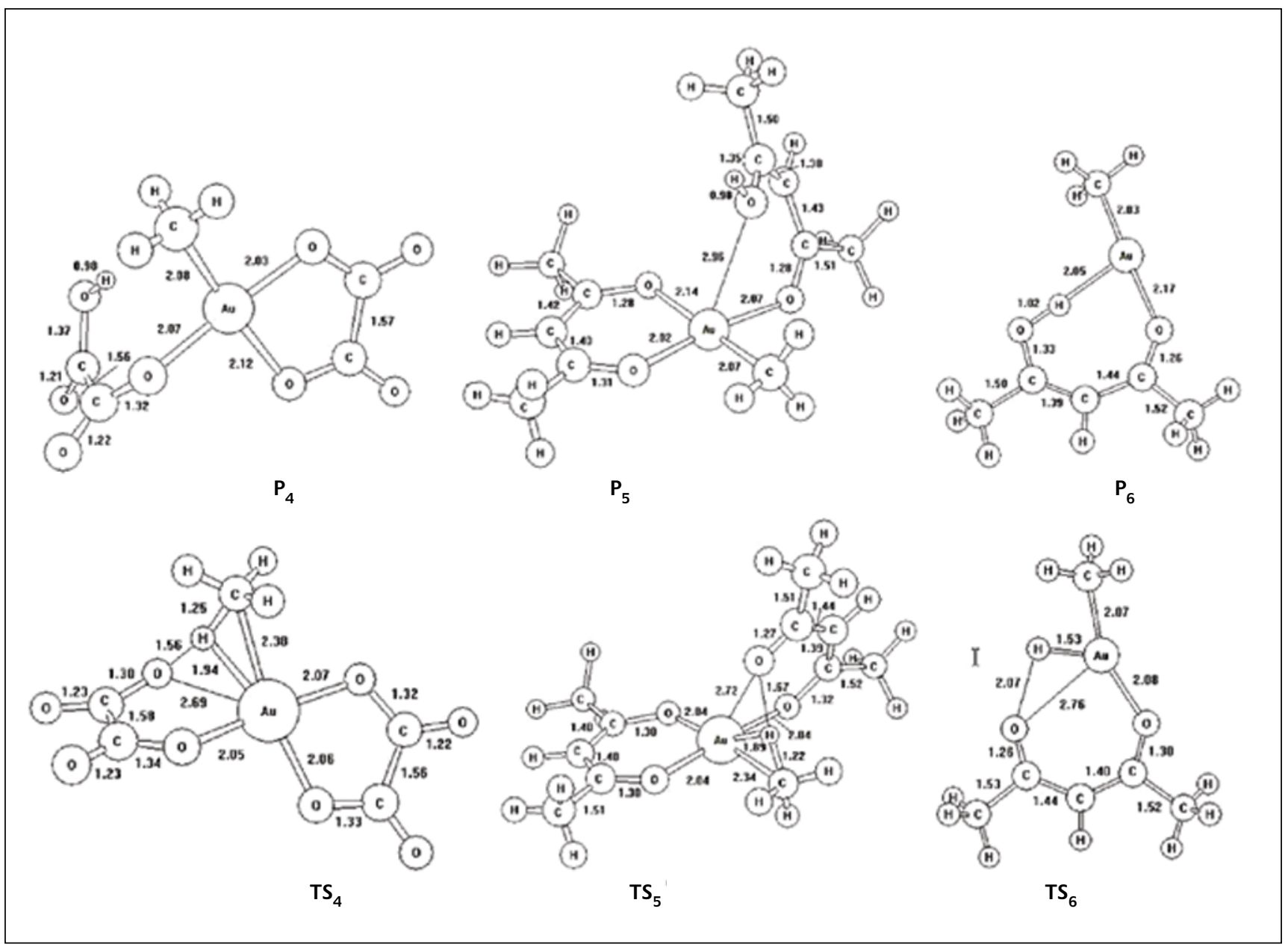

Figure 4

Structures of the $\left[\mathrm{Au}\left(\mathrm{CH}_{3}\right)(\mathrm{OH})_{3}\right]$, $\left[\mathrm{Au}\left(\mathrm{CH}_{3}\right)\left(\mathrm{OCH}_{3}\right)_{3}\right]$, $\left[\mathrm{Au}\left(\mathrm{CH}_{3}\right)(\mathrm{HCOO})(\mathrm{OCHOH})\right]$ complexes $\left(\mathrm{P}_{1}, P_{2}, \mathrm{P}_{3}\right)$, transition states of reactions (1), (2) and (3) (TS, $\mathrm{TS}_{2}$, $T_{3}$ ) and the calculated bond lengths (Å) 
conditions, moreover it has a sufficient energy gain of -32.7 $\mathrm{kcal} / \mathrm{mol}$.

\section{Simulation of the reaction of acetylacetonatogold complexes with methane}

Acetylacetonato (acac) is a classical ligand in coordination chemistry. The chemistry of acac complexes has mainly been focused on their reactions with Lewis bases and electrophilic substitution reactions giving 3-carbon substituted acac complexes (21). So reactions between the acac gold complexes ([Au'"(acac $\left.\left.)_{2}\right]^{+},\left[\mathrm{Au}^{\prime}(\mathrm{acac})\right],\left[\mathrm{Au}^{\prime}(\mathrm{acac})_{2}\right]^{-}(22)\right)$ and methane may be expected. First the $\left[\mathrm{Au} \text { "' }(\mathrm{acac})_{2}\right]^{+}$complex $\left(R_{5}\right)$ was considered:

$$
\left[\mathrm{Au}^{\prime \prime \prime}(\mathrm{acac})_{2}\right]^{+}+\mathrm{CH}_{4}=\left[\mathrm{Au}^{\prime \prime \prime}\left(\mathrm{CH}_{3}\right)(\mathrm{acac})(\mathrm{acacH})\right]^{+}
$$

We found the near resemblance between $P_{5}$ and $P_{4}$ and corresponding transition states. The reaction (7) is endothermic $(5.2 \mathrm{kcal} / \mathrm{mol})$ and has quite a high activation energy $(39.2 \mathrm{kcal} / \mathrm{mol})$.

It is a common knowledge that the gold(I) compounds are more reactive than gold(III) compounds, so the reaction of methane with $\left[\mathrm{Au}^{\prime}(\mathrm{acac})\right]$ was also simulated (Figure 1):

$$
\left[\mathrm{Au}^{\prime}(\mathrm{acac})\right]+\mathrm{CH}_{4}=\left[\mathrm{Au}^{\prime}\left(\mathrm{CH}_{3}\right)(\mathrm{acacH})\right]
$$

The most stable product of electrophilic substitution ( $P_{6}$, Figure 4) has an interesting feature. A hydrogen atom bonded to an O-atom from acac ligand (1.02 $\AA$ ) is only a very short distance to the Au atom (2.05 $\AA$ ). The relaxation of the $\mathrm{TS}_{6}$ means that reaction (8) takes place via methane complex formation (this structure isn't presented). This is accompanied by a slight decrease in the free energy on 0.5 $\mathrm{kcal} / \mathrm{mol}$. Reaction (8) is exothermic $(-29.1 \mathrm{kcal} / \mathrm{mol})$ and has a low energy barrier of $9.3 \mathrm{kcal} / \mathrm{mol}$.

The first step of $\mathrm{C}-\mathrm{H}$ bond activation in methane by a gold(I) complex can also proceed via an oxidative addition mechanism. The corresponding reaction of $\left[\mathrm{Au}^{\prime}(\mathrm{acac})\right]$ was also considered:

$$
\left[\mathrm{Au}^{\prime}(\mathrm{acac})\right]+\mathrm{CH}_{4}=\left[\mathrm{Au}^{\prime \prime \prime}(\mathrm{H})\left(\mathrm{CH}_{3}\right)(\mathrm{acac})\right]
$$

The simulation of this reaction demonstrates that it is exothermic $(-24.6 \mathrm{kcal} / \mathrm{mol})$ and has a low energy barrier (10.9 kcal/mol), but reaction (8) is preferable from a thermodynamic viewpoint.

Methane functionalization via gold complexes takes place when the oxygen is present. So, Au-O bond formation may also be possible as a first step. In this case methanol is formed from methane and a molecular or atomic form of oxygen gold complex according to the schemes:

1. $\left[\mathrm{Au}^{\prime}(\mathrm{acac})\right]+\mathrm{O}_{2}=[\mathrm{Au}(\mathrm{O})(\mathrm{O})(\mathrm{acac})]+58.8 \mathrm{kcal} / \mathrm{mol}$; $[\mathrm{Au}(\mathrm{O})(\mathrm{O})(\mathrm{acac})]+\mathrm{CH}_{4}=\mathrm{CH}_{3} \mathrm{OH}+[\mathrm{Au}(\mathrm{O})(\mathrm{acac})]+2.8 \mathrm{kcal} / \mathrm{mol}$; $[\mathrm{Au}(\mathrm{O})(\mathrm{acac})]+\mathrm{CH}_{4}=\mathrm{CH}_{3} \mathrm{OH}+[\mathrm{Au}(\mathrm{acac})]+26.6 \mathrm{kcal} / \mathrm{mol}$.
2. $\left[\mathrm{Au}^{\prime}(\mathrm{acac})\right]+\mathrm{O}=[\mathrm{Au}(\mathrm{O})(\mathrm{acac})]+134 \mathrm{kcal} / \mathrm{mol}$; $[\mathrm{Au}(\mathrm{O})(\mathrm{acac})]+\mathrm{CH}_{4}=\mathrm{CH}_{3} \mathrm{OH}+[\mathrm{Au}(\mathrm{acac})]+26.6 \mathrm{kcal} / \mathrm{mol}$

Only the energy difference between those of the products and the initial substances are calculated. For clearer conclusions about the mechanism information on corresponding transition states is necessary.

\section{Conclusion}

To summarize, we have performed quantum-chemical simulation calculations of methane bond activation by gold complexes with oxygen-containing ligands, i.e. $[\mathrm{Au}(\mathrm{OH})]^{-}$, $\left[\mathrm{Au}\left(\mathrm{OCH}_{3}\right)_{4}\right]^{-}, \quad\left[\mathrm{Au}\left(\mathrm{O}(\mathrm{CO})_{2} \mathrm{O}\right)_{2}\right]^{-}, \quad\left[\mathrm{Au}(\mathrm{HCOO})_{2}\right]^{+}, \quad\left[\mathrm{Au} \mathbf{l}^{\prime}(\mathrm{acac})\right]$ and $\left[\mathrm{Au}^{\prime \prime \prime}(\mathrm{acaC})_{2}\right]^{+}$. Based on the calculated structures of the reactants, the products and the transition states, high activation energies (higher than $35 \mathrm{kcal} / \mathrm{mol}$ ) were found for the reactions of methane with most of the complexes studied, excluding the possibility of occurrence of these processes under mild conditions.

Only for the reaction of methane with $\left[\mathrm{Au}(\mathrm{HCOO})_{2}\right]^{+}$and $\left[\mathrm{Au}^{\prime}(\mathrm{acac})\right]$ complexes are intermediate methane complexes formed and these transform to the corresponding methyl complexes with a low energy barrier.

In our opinion, these studies of methane activation by gold complexes offer new possibilities for the design of systems for the functionalization of alkanes and information about reaction between methane and $\left[\mathrm{Au}^{\prime}(\mathrm{acac})\right]$ complex could help to clarify the mechanism of methane oxidation by the Au-rutin complex (11).

\section{Acknowledgements}

This study was financially supported by the Council on Grants of the President of the Russian Federation (MK-3156.2007.3) and the Russian Foundation for Basic Research (Project N 0603-33131-a). 
About the authors

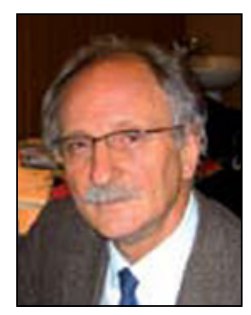

Prof. NE Kuz'menko is Professor of Physical Chemistry at the M.V. Lomonosov Moscow State University. He carried out his Diploma and PhD in the field of theoretical chemistry and molecular spectroscopy. $\mathrm{He}$ is currently Head of the Laboratory of Molecular Spectroscopy and Vice-Dean of the Chemistry Department of MSU.

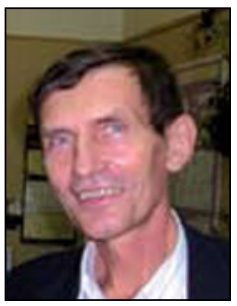

Doctor of Science AF Shestakov DSC is Head of the Laboratory of Transition Metal Catalysis in the Institute of Problems of Physical Chemistry. The scope of his scientific interests is the theoretical study of activation of small molecules in the coordination sphere of transition metal complexes, i.e. C-H bond activation and nitrogen fixation.

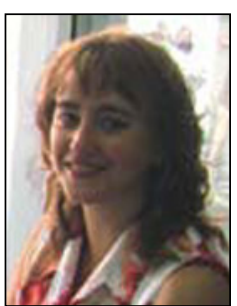

DA Pichugina PhD works in Professors N.E. Kuz'menko's and A.F. Shestakov's group where they study the interaction and reactions of small molecules with gold nanoclusters and gold compounds using quantum chemistry methods.

\section{References}

1 A. E. Shilov, Metal Complexes in Biomimetic Chemical Reactions, CRC Press, Boca Raton-New York, 1997, 302

2 A. E. Shilov and A. A. Shteinman, Coord. Chem. Rev., 1977, 24, 97

3 W. R. Mason and H. B. Gray, J. Am. Chem. Soc., 1968, 90, 5721

4 M. S. Kharash and H. S. Isbel, J. Am. Chem. Soc., 1931, 53, 3053

5 Y. Fuchita, Y. Utsunomiya and M. Yasutake, J. Chem. Soc., Dalton Trans., 2001, 2330

6 G. B. Shul 'pin, J. Organomet. Chem., 1981, 212, 267

7 A. S. K. Hashmi, Gold Bull., 2004, 37, 51

8 A. S. K. Hashmi, J. P. Weyrauch, M. Rudolph and E. Kurpejovic, Angew. Chem. Int. Ed., 2004, 43, 6545

9 S. Komiya, T. Sone, Y. Usui, M. Hirano and A. Fukuoka, Gold Bull., 1996, 29, 131

10 C. J. Jones, D. Taube, V. R. Ziatdinov, R.A. Periana, R.J. Nielsen, J. Oxgaard and W. A. Goddard III, Angew. Chem. Int. Ed., 2004, 43, 4626

11 L. A. Levchenko, A. P. Sadkov, N. V. Lariontseva, E. M. Koldasheva, A. K. Shilova and A. E. Shilov, Dokl. Akad. Nauk, 1999, 364, 117 ; Dokl. Chem., 1999 (Engl. Transl.)

12 D. Malesev, Z. Radovic, M. Jelikic-Stankov and M. Bogavac, Anal. Lett., 1991, 24, 1159

13 L. A. Levchenko, A. P. Sadkov, N. V. Lariontseva, V. S. Kulikova, A. K. Shilova, and A. E. Shilov, Dokl. Akad. Nauk, 2004, 394, 2; Dokl. Chem., 2004 (Engl. Transl.)

14 H. G. Raubenheimer and S. Cronje, Gold: Progress in Chemistry, Biochemistry, and Technology, Ed. H. Schmidbaur, Wiley, Chichester, 1999, 588

15 D.A. Pichugina, A.F. Shestakov and N.E. Kuz'menko, Russ. Chem. Bull., Int. Ed., 2006, 55, 195

16 J. P. Perdew, K. Burke and M. Ernzerhof, Phys. Rev. Lett., 1996, 77, 3865

17 D. A. Pichugina, A. F. Shestakov, and N. E. Kuz'menko, Zh. Fiz. Khim., 2004, 78, 2027; Russ. J. Phys. Chem., 2004 (Engl. Transl.).

18 D. N. Laikov, Chem. Phys. Lett., 1997, 281, 151

19 H. Basch and P. G. Jasien, Can. J. Chem., 1992, 70, 612

20 C. Gonzalez and H. B. Schlegel, J. Chem. Phys., 1989, 90, 2154

21 J. Vicente and M.T. Chicote, Coord. Chem. Rev., 1999, 193, 1143

22 J. Vicente, M.T. Chicote, M. M. Alvarez-Falcon and P. G. Jones, Chem. Commun., 2004, 2658 